\section{A construção de espaços públicos na política educacional em Gurupá, Pará, Brasil}

\author{
Émina Márcia Nery dos Santos \\ emina@ufpa.br \\ Tese de Doutorado \\ Programa de Pós-Graduação em \\ Desenvolvimento Sustentável do Trópico Úmido \\ Núcleo de Altos Estudos Amazônicos \\ Universidade Federal do Pará \\ Belém (PA) 2008
}

\section{The construction of public spaces in the educational policies in Gurupá, state of Pará, Brazil}

\author{
Émina Márcia Nery dos Santos \\ emina@ufpa.br \\ Doctoral Thesis \\ Pos-Graduation Program in \\ Sustainable Development in the Humid Tropics \\ Nucleus of High Studies of the Amazon \\ Federal University of Pará \\ Belém (PA) - Brazil 2008
}

Essa tese de doutorado é fruto de uma pesquisa dedicada a sistematizar a origem dos espaços públicos de decisão na gestão da política educacional de Gurupá, município paraense localizado no arquipélago do Marajó. Constitui seus objetivos principais o exame do processo de construção de canais que potencializam a participação cívica da sociedade na proposição e consolidação de políticas educacionais locais; da intensidade, dos vínculos, dos fluxos relacionais e da qualidade da participação dos agentes sociais, assim como das perspectivas de continuidade e descontinuidade de atuação das instâncias populares nas proposições das políticas públicas locais a partir de sua atuação e do seu envolvimento nos espaços públicos. Utilizou-se como procedimento metodológico a concepção de redes sociais como ferramenta capaz de mapear a articulação entre instâncias da sociedade civil envolvidas com a concepção e execução da educação municipal. O corte histórico proposto no plano das ações organizativas é o final da década de 1970, quando da implementação das Comunidades Eclesiais de Base na região, e no plano das orientações da Constituição Federal de 1988, que dotou o município da condição de ente federativo, capaz de se autogerir.
This research is devoted to systematize the origin of public spaces for decisions in the management of Gurupá educational policies, a city located in the archipelago of Marajó. The main objectives are to analyze the construction of channels which support the civil society participation in proposing and establish local educational policies; the intensity, links, relational flowing, and quality participation of the social agents, as well as the prospects of continuity and discontinuity around the role of popular movements, proposing local public policies from their actions and involvement in the public spaces. The methodological procedure adopted the social networks as a tool capable of mapping the joint of civil society organizations involved with the development and the implementation of municipal education. The historical perspective comprehends the decade of 1970s, when the 'Comunidades Eclesiais de Base' were implemented in the region, and the decade of 1980s, when the Federal Constitution of 1988 considered municipalities into the federative system with political autonomy. 